\title{
Forecasting Change Based on Employees' Work Engagement: Case Study (Civil Servants in Government Organizations in Sanandaj)
}

\author{
Khaled E'temad ${ }^{1, b^{*}}$, Hossein Rahmanseresht ${ }^{2, b}$ \\ 'Master's Degree Student in Business Administration, majoring in Change, Sanandaj Branch, \\ Islamic Azad University, Sanandaj, Iran \\ ${ }^{2}$ A Faculty Member of Allameh Tabatabaei University in Tehran, Iran \\ a'Kh.etemad@gmail.com, ${ }^{b} \mathrm{Hrahmanseresht@gmail.com}$
}

Keywords: work engagement, change acceptance, government agencies in Sanandaj

\begin{abstract}
The study tries to identify predictors of change acceptance based on work engagement of civil servants in government organizations in Sanandaj. The population of the study is 4235 civil servants in government organizations in Sanandaj. The present study uses stratified random sampling method. Using Cochran's Formula, as many as 352 people were set as the sample size and the same number of questionnaires was filled by the participants. The study was descriptive co relational and was carried out through a descriptive method. A questionnaire was used for data collection to measure the level of work engagement, the questionnaire proposed by Schaufeli and Becker (2003) was used. To measure change acceptance in the respondents, the questionnaire proposed by Saeatchi, Kamkari and Askarian (2010) was designed according to the model by Kurt Lewin. After the validity and reliability of the questionnaires were confirmed, the questionnaires were distributed among the participants. Cronbach's alpha in work engagement and in change acceptance questionnaires were 0.84 and 0.82 , respectively. After completing the questionnaire using SPSS20, Pearson correlation analysis and multivariate regression analysis were calculated and analyzed. The results of regression analysis showed that the dependent variable (change acceptance) was directly affected by liveliness and eagerness of the staff. This variable alone explains $44 \%$ of acceptance of change variance in this study. The independent variable is directly affected by eagerness variable. This variable alone accounts for $39 \%$ of accepting change variance in the population under study. The third determinant of accepting change is the employees' dedication variable. This variable alone amounts to $31 \%$ of change acceptance variance by staff in the population under study.
\end{abstract}

\section{INTRODUCTION}

Organizations require dynamism and constant change and innovation to survive. The world is constantly changing and according to Deracker, the only constant thing in today's world is change. If there was no need for change and innovation, men still lived in the first place and perhaps at the same level of living animals and no other change in knowledge, attitudes and behavior would result. If humans were not flexible to accept change, they would be confined to their narrow-minded views and their progress would be blocked. As a result, in today's competitive world, the need for rapid changes in the organization and management is one of the basic conditions of organizational success (Bakhshi, 2011: 100). Organizations are influenced by interior or exterior environment conditions which are changing (Frazja \& Khademi, 2011: 50). One of the variables affecting change is work engagement. Shaufeli and Becker (2003) define work engagement as positive mental states, satisfaction and work-related featured by three indicators of vitality, dedication and attention and absorption. Vitality is distinguished by a high level of energy and mental resilience. Intense devotion can be seen as the involvement of a person with significant work and experiencing a sense of enthusiasm and challenge. Attention and absorption features full concentration and absorption, whereby time passes quickly and separation from work becomes difficult (Shaufley and Pristine, 2003, 5-6).Creating employees' satisfaction, work engagement and organizational commitment are not possible without satisfying the needs of employees. According to Maslow's hierarchy, there is a 
need for respect and acquisition of a social identity, which can be possible through a prestigious job. Work engagement can include individual interests and desire to perform duties in the organization. Such flow of energy, in addition to extra energy it creates in people, can be useful for the individual himself and the whole society. Work engagement is necessary for all jobs.

A sense of organizational engagement can help managers to ensure the presence of individuals and set design with regard to this assurance to carry out long-term plans (Bakker, A. B. Demerouti, and E. 2007, 211). A wide range of studies on work engagement show an important necessity as a priority on the top of activities of the managers in organizations. Appropriate understanding and recognition of work engagement of employees can improve management plans to get prepared for short-term, medium-term and long-term plans. It can organize itself to deal with the market full of change, evolution and competition. According to the stated purpose of this study, the aim of this study is to identify the relationship between work engagement, acceptance of change by their employees and sub-objectives including identifying the relationship between the vitality, dedication (devotion) and accepting changes by employees.

\section{REVIEW OF LITERATURE}

\section{Part 1: Concept and definition of work engagement}

The term engagement of employees over the past decade has become one of the hot topics in management (Macey, W. H., \& Schneider, 2008: 4). So far, a lot of definitions of the definitions of different types of engagement have been provided. Rothbard (2001) defines psychological attachment as the tendency towards a state in which there are two main components of attention and absorption. 'Attention' refers to the availability of cognitive and the amount of thought a person spends on thinking about his own role. While the "attention and absorption" means getting immersed and is highly focused on the role of the individual in a role (Rothbard, 2001: 656), Macy et al (2009) know it as belonging to an individual's sense of purpose and focus on finding energy for others in the form of displaying individual initiative, adaptability, and inclination toward organizational goals.

\section{Dimensions of work engagement}

Researchers have considered various aspects of work engagement. From the perspective of Macy et al. (2009), work engagement has two aspects of mental energy (inside or feel) and behavioral energy (outside or look). However, according to the definition Shaufeli and Bakkar (2003) see work engagement as positive mental state and work-related distinguished by three indicators of vitality, dedication and absorption and attention.

1. Vitality: the high levels of energy and mental resilience while working, in particular. In this case, the person tends to put more effort in their work and the problems of persistent work and tirelessness.

2. Self-sacrifice (sacrifice): It indicates the deep involvement of the individuals, meaningful work experience, passion and challenge.

3. Absorption and attention: It is distinguished with complete concentration and happy absorption at work, whereby time passes quickly and it is difficult to separate themselves from work (ibid: 2423).

\section{Part 2: Acceptance of Change}

\section{The nature of change and its definition}

Organizational change may not occur spontaneously. Change intriguers normally originate from the organizational environment or market. These drivers include bold moves by competitors, new technology or change in government regulations. The inefficiency of a manager is an impetus for change in the organization. The only thing that is constant in organizations is change. It is necessary to understand the process of change. Organizations as a whole specifically do not like to hear the word change. The term change has unpleasant connotations for them (Ledez, 2011: 111). Romanelli 
and Tushman (1994) state that change occurs in five areas of organizational activity: organizational culture, strategy, structure, power distribution and monitoring systems. Survival is not possible without them. All activities of the organization happen within the five areas. Each of these areas, although specific activities, but also linked to each other. Inconsistent and inappropriate activities within each of these areas will lead to reduced performance or failure.

\section{A review on experimental studies and setting a theoretical framework}

The findings from Rahmanseresht and Moghadam (2007) suggest that the kind of interpretation that managers offer of real events and their attitude toward the process of organizational change affect their decision on the actions to adopt effective organizational changes. The results from Ghorbanzadeh and Akbari (2007) have shown that individual and organizational characteristics play a major role in the acceptance of organizational change. The results from the research by Barbaroux (2011) have shown that change in military organizations lead to reconstruction and regulation of communications and change in organizational structures.

The results from the study carried out by Richard Soparnot (2011) suggest that change capacity depends on management to a large extent and dependent on the conditions within the organizations. The study done by Bakker A. B., Demerouti E. (2007) found that the combination of high job requirements with little job resources could predict burnout (exhaustion and cynicism) significantly. Work engagement dimensions include the three dimensions of vitality, dedication and attention and absorption (Shaufeli and Bakkar, 2003) and the acceptance of change based on Kurt Lewin's Model (Saatchi et al., 2010).

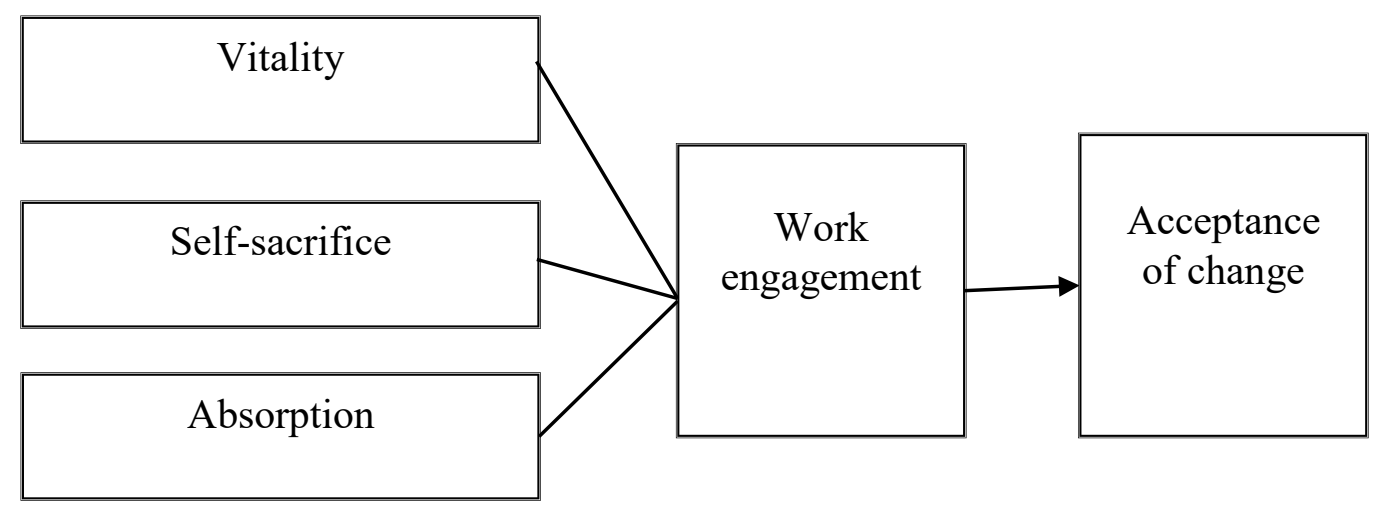

Figure 1: Conceptual Framework of the Study (Kurt Lewin, 2003; Shaufelin, 2003)

\section{The hypotheses of the study are as follows:}

\section{A: Main hypothesis}

- There is a significant relationship between civil servants' work engagement and their acceptance of change

\section{B: Secondary hypotheses}

- There is a significant relationship between civil servants' vitality and their acceptance of change

- There is a significant relationship between civil servants' self-sacrifice and their acceptance of change

- There is a significant relationship between civil servants' attention and absorption and their acceptance of change 


\section{METHODOLOGY}

The study is a descriptive co relational study and the population consists of the whole civil servants, as many as 4235 people, in government organizations in Sanandaj in 2015.Based on Cochran Smith's Formula, 352 people were selected as the sample. A stratified sampling method was used for the sampling. Data collection was done using standard questionnaires. To measure the level of work engagement, a relevant questionnaire designed by Shauflei and Bakkar (2003) was used. The questionnaire contains 17 items. The questionnaire contained the vitality, dedication and attention and absorption variables with 6,5 and 6 items, respectively. Cronbach's alpha coefficient of this scale in the selected samples was 0.938 and quite acceptable. To measure changes in staff acceptance of change, an attitude questionnaire by Saatchi, Kamkari and Askarian (2010) was used, which was designed based on the Kurt Lewin model. Using Cronbach's alpha, the reliability of work engagement and change acceptance questionnaires were 0.84 and 0.82 .To analyze the data, descriptive statistical analysis methods (including tables and graphs, measures of central tendency and dispersion, frequency, etc.) and inferential statistics, correlation analysis, regression) were used. In this study, statistical analysis was performed using SPSS. In Table 1, the distribution of the sample is provided.

\section{FINDINGS OF THE STUDY}

\section{A. Descriptive statistics}

Having examined the participants separately, the distribution of gender, age, education and work experience were shown in the following table.

Table 1 Shows the distribution of participants according to demographic variables

\begin{tabular}{|c|c|c|c|}
\hline Percentage & Frequency & \multicolumn{2}{|c|}{ Variable } \\
\hline 56.8 & 200 & male & \\
\hline 43.2 & 152 & female & Age \\
\hline 21.6 & 76 & 21 to 30 years & \\
\hline 63.4 & 223 & 31 to 40 years & Occupational \\
\hline 15.1 & 53 & 41 to 50 years & Record \\
\hline 78.1 & 275 & Under 10 years & Education \\
\hline 12.8 & 45 & 11 to 20 years & \\
\hline 9.1 & 35 & High School Diploma & \\
\hline 8 & 28 & Associate's Degree & \\
\hline 17 & 60 & Bachelor's Degree & \\
\hline 23.3 & 182 & Master's Degree \& Higher & \\
\hline
\end{tabular}

\section{Descriptive statistics related to work engagement of the participants}

This variable included a total of 17 items. According to Table 2, it can be said that average employee engagement in the study population was 54.6 out of a minimum score of 17 and a maximum score of 85 , which was higher than the average (mean $=54.6)$ and indicated that the amount of work engagement of employees in the population under study was moderate to high.

Table 2: Descriptive statistics on the engagement of employees and its components

\begin{tabular}{cccccccc}
\hline Status & $\begin{array}{c}\text { No } \\
\text { of } \\
\text { Items }\end{array}$ & SD & Mean & $\begin{array}{c}\text { Maximum } \\
\text { of } \\
\text { Statistic }\end{array}$ & $\begin{array}{c}\text { Minimum } \\
\text { of } \\
\text { Statistic }\end{array}$ & Number & Variable \\
\hline $\begin{array}{c}\text { Average } \\
\text { and over }\end{array}$ & 17 & 8.07 & 54.6 & 69 & 40 & 352 & $\begin{array}{c}\text { work } \\
\text { engagement } \\
\text { vnder }\end{array}$ \\
$\begin{array}{c}\text { vitality } \\
\text { Average }\end{array}$ & 6 & 2.5 & 15.7 & 21 & 12 & 352 & self-sacrifice \\
$\begin{array}{c}\text { Average } \\
\text { and over }\end{array}$ & 5 & 3.9 & 16.3 & 25 & 10 & 352 & absorption \\
Average & 6 & 2.3 & 17.8 & 22 & 13 & 352 & \\
\hline
\end{tabular}




\section{Descriptive statistics on the acceptance of change by civil servants}

The variable included a total of 18 items. According to Table 3, it can be noted that the acceptance of change by employees in the study population was a bit higher than the average (mean $=56.5$ out of at least 18 and a maximum of 90 ).

Table 3 Descriptive statistics related to acceptance of change among employees

\begin{tabular}{cccccccc}
\hline Status & $\begin{array}{c}\text { No } \\
\text { of } \\
\text { Items }\end{array}$ & SD & Mean & $\begin{array}{c}\text { Maximum } \\
\text { of } \\
\text { Statistic }\end{array}$ & $\begin{array}{c}\text { Minimum } \\
\text { of } \\
\text { Statistic }\end{array}$ & Number & Variable \\
\hline $\begin{array}{l}\text { Average } \\
\text { and over }\end{array}$ & 18 & 8.8 & 56.5 & 73 & 29 & 352 & $\begin{array}{c}\text { acceptance } \\
\text { of change }\end{array}$ \\
\hline
\end{tabular}

\section{(B) Testing the hypotheses: Fitting model of dependent variable determinants}

In this study, multiple regression analysis, using step-by-step was done. The regression analysis showed that the variables of vitality, dedication and attention and absorption explain a net $38 \%$ of change acceptance in the studied population.

Table 4 Multivariate regression analysis of tendency to quit based on the organizational justice

\begin{tabular}{cccccc}
\hline Sig. & F statistic & SD & $\begin{array}{c}\text { Corrected } \\
\text { Explained } \\
\text { Coefficient }\end{array}$ & $\begin{array}{c}\text { Explanation } \\
\text { Coefficient }\end{array}$ & $\begin{array}{c}\text { Correlation } \\
\text { coefficient }\end{array}$ \\
\hline 0.000 & 71.064 & 2.13 & 0.375 & 0.380 & 0.616 \\
\hline
\end{tabular}

Table 5 Statistics related to independent variables in regression models

\begin{tabular}{cccccc}
\hline Sig. T & T & Beta & Std. B & B & Variable \\
\hline 0.000 & 10.718 & - & 3.779 & 40.507 & origin \\
\hline 0.000 & 6.739 & 0.392 & 0.218 & 1.470 & absorption \\
\hline 0.000 & 7.70 & 0.443 & 0.137 & 1.054 & vitality \\
\hline 0.000 & 4.307 & 0.312 & 0.163 & 0.704 & self-sacrifice \\
\hline
\end{tabular}

The dependent variable is impacted by the independent variable in the following order:

1. Vitality of Staff: $44 \%$ of variance from the dependent variable

2. Attention and absorption: $39 \%$ of variance from the dependent variable

1. Self-sacrifice: $31 \%$ of variance from the dependent variable

The final model of multivariate regression analysis in this study is as follows:

Accepting change $=($ Sacrifice $)+($ attention and absorption $)+($ vitality $)$

\section{CONCLUSION \& RECOMMENDATIONS}

Based on the results of this research, the attention and absorption of organization employees after the indicator of the vitality of staff had the most direct impact on the staff to accept change. Attention and absorption with full concentration and happy absorption differ at work, whereby time passes quickly and is difficult to separate themselves from work (Shaufeli and Bakkar, 2003: 2423).

The results show that this method is effective to inhibit, regulate and guide our motivation. Employees who are attracted to their jobs, unlike some other employees, do not stop working easily and may feel a moral obligation to get immersed in their jobs. In such circumstances, members do certain behaviors that go beyond the minimum level required to perform a task. People with attachment, usually exhibit more stability in work, are more initiative and expand the scope of their role.

Then entrepreneur people are more likely to experience work engagement. Empirical evidence suggests that this category has a positive relationship with organizational outcomes such as job performance, stress tolerance in demanding jobs, leadership effectiveness, organizational innovation and entrepreneurship (Isakhani, 2012: 82). 
Based on the results of the research, self- sacrifice was the third variable with a direct impact on the staff to accept change. Self-sacrifice involves serious personal and experiential engagement. The person feels a sense of meaningful work, passion and a challenge (ibid: 24-23). In fact, these behaviors increase confidence among the staff. People with this feeling, keep on working in the worst conditions, and even in the case of disease and disability, they continue to work together, which indicates their high conscientiousness. This dimension deals with good and efficient behaviors such as intimacy, empathy and compassion among colleagues, which either directly or indirectly helps the employees who have work problems. Consequently, dedicated employees reduce complaining, blame and criticism and further regulate their time for corporate activities.

\section{Based on the findings, the following recommendations are put forward}

1- It is recommended to increase the employees' engagement in organizational identity, organizational justice, trust, commitment and leadership style because these factors with these behaviors have shown a significant relationship in companies and organizations. The consequences of work engagement such as customer satisfaction, customer loyalty, spiritual and social capital, image and prestige rise. Hence, it is recommended that these organizations set strengthening organizational identity, increasing trust and organizational justice a priority in the direction of their organizational policies.

2- Good-paying job is a good strategy for improving engagement. Organizations that work to foster engagement generally pay good salaries to their employees and involve them in profit sharing of their organizations.

3- Employees and managers should reinforce positivism in their employees and try not to exaggerate problems and try to find ways out of problems instead of complaining.

4- It is proposed to allow employees to express their views. People can express their individual views. In this case, people can internalize their jobs and treat it as a major aspect of their concept.

\section{References}

[1] Bakhshi, N. (2011). Organizational change. Monthly Periodical of Labor \& Society, No. 2011: 67-60.

[2] Rahmanseresht, H.; Moghadam, A. (2007). The role of mental models in the process of organizational change (case study is one of the companies producing tissue paper). Journal of Management, 78, 3-24.

[3] Saatchi, Mahmoud; Kamkari, K., Askarian, M. (2010). Psychological tests, Tehran. Virayesh Publication.

[4] Isakhani, A. (2013). Explaining the role of occupational and personal resources in work engagement. Public Administration, 5 (2): 73-96.

[5] Isakhani, A., Fani, A. Danaeefard, H. (2012).The relationship between work engagement and organizational commitment. Public Management Research Quarterly, 16: 23-38.

[6] Frazja, M. and Khademi, M. (2011). The relationship between transformational leadership style and interactionist and attitude to organizational change, Quarterly of New Ideas in the Journal of Education, sixth years, fourth edition, Fall 2011, pp. 69-49.

[7] Ghorbanzadeh, D.; Akbari, M. (2010). Personal characteristics and organizational role in the adoption of organizational changes, Paper presented at the Fifth International Conference on Management, Tehran, 27 to 29 December.

[8] Barbaroux, P. (2011). A design-oriented approach to organizational change: insights from a military case study. Journal of Organizational Change Management, 24(5), 626-639.

[9] Bakker, A. B., \& Demerouti, E. (2007). Towards a model of work engagement. Career development international, 13(3), 209-223. 
[10] Ledez, R. E. (2011). Change management: getting a tuned up organization. Human Resource Management: Issues, Challenges and Opportunities, 73.

[11] Macey, W. H., \& Schneider, B. (2008). The meaning of employee engagement. Industrial and organizational psychology, 1(1), 3-30.

[12] Macey, W.H., Schneider, B., Barbara, K.M., Young, S.A. (2009). Employee engagement: Tools for analysis, practice and competitive advantages. Willey- Blackwell, UK

[13] Papadakis, V. M., Lioukas, S., \& Chambers, D. (1998). Strategic decision-making processes: the role of management and context. Strategic management journal, 19(2), 115-147.

[14] Rothbard, N.P. (2001). Enriching or depleting? The dynamics of engagement in work and family roles. Administrative Science Quarterly, 46(4): 655-684.

[15] Soparnot, R. (2011). The concept of organizational change capacity. Journal of Organizational Change Management, 24(5), 640-661.

[16] Schaufeli, W. B., \& Bakker, A. B. (2003). Utrecht work engagement scale: Preliminary manual. Occupational Health Psychology Unit, Utrecht University, Utrecht. 